\title{
ECONOMIC SECURITY AS AN ELEMENT OF THE REGION'S DEVELOPMENT PROCESS ON THE EXAMPLE OF COMMUNES OF THE ŚWIĘTOKRZYSKIE VOIVODSHIP
}

\author{
Piotr Wiraszka ${ }^{1}$, Urszula Karpinska ${ }^{2}$
}

\begin{abstract}
Economic security can be described as a process, in which one seeks to achieve a state of calmness and the ability to neutralize emerging threats, in a geographically or culturally defined space, in which an individual, legal entity or territory has a feeling similar to certainty that they have and will have sufficient the amount of resources to cover current needs and that there will be no risky situations that would deprive these entities of their resources. The aim of the article is to assess the diversification of economic security of communes in the Świętokrzyskie Voivodship in 2009-2018, using a synthetic measure. Empirical data were collected in spatial terms for 102 communes of the Świętokrzyskie Voivodship. The material used was data from the Local Data Bank of the Central Statistical Office and the Regional Accounting Chamber of Kielce for 2009-2017. When discussing the activities of local entities in the process of shaping economic security, the first thing to emphasize is the importance of Local Government Units (LGUs), the operation of which is key in ensuring the continuity of the development process and striving to ensure an adequate level of security. Economic security is expressed primarily in the economy's ability to survive and develop. The greater the economic potential of the national economy is at a higher level of socioeconomic development and shows faster growth dynamics, the more stable and durable its security is considered. The study showed a diversified level of financial security for communes in the Świętokrzyskie Voivodship. In 2018, the measure of the level of financial security ranged from 0.65 to 0.85 , while from 0.69 to 0.87 in 2009 .
\end{abstract}

Key words: regional development, economic security, commune.

JEL Classification: F52

\section{Introduction}

Economic security is a concept covering several scientific disciplines and it is multidimensional due to the entity, to which it relates. Local economic security can be defined as a process, in which one seeks to achieve a state of calmness and the ability to neutralize emerging threats in the local space, geographically or culturally defined, which aims to ensure stability and security of development for every citizen. The purpose of the article is to identify factors that, in the geographical and social context, affect the level of economic security of the studied region and stimulate its development.

The local dimension of security is still gaining importance given the general socio-civilization trends, as well as the increase in the value of the region's importance in the economic, social aspect, created by the European institutions. The result is the observed increase in the importance of small local communities and the locality, its security and creating development opportunities become a driving force that deserves attention and protection. In local terms, security concerns people, groups of people, various organizations, and formalized, and territorially recognizable administrative and state structures such as commune, poviat and voivodship (Kitler, 2010). We can also approach the problem of security in the subject system. Then, we are talking about military, political, economic, ecological, social or cultural security (Stańczyk, 1996). J. Marczak defines security as a state, sense, process, goal, value, need, structure.

When discussing the activities of local entities in the process of shaping the development of the region and its security, the first thing to note is the importance of the Local Government Units (LGUs), the operation of which is key when it comes to regional development and shaping this development and striving to ensure the security of this development.

\footnotetext{
Corresponding author:

${ }^{1}$ The Apeiron School of Public and Individual Security in Krakow, Poland.

E-mail: wiraszkapiotr@wp.pl

ORCID: https://orcid.org/0000-0002-0128-5146

${ }^{2}$ Cooperative Bank in Kielce, Poland.

E-mail: Urszula.Karpinska@bskielce.com.pl

ORCID: https://orcid.org/0000-0002-4032-8823
} 


\section{Material and research method}

The aim of the article is to assess the diversification of economic security of communes in the Świętokrzyskie Voivodship in 2009-2018, using a synthetic measure. Empirical data were collected in spatial terms for 102 communes of the Świętokrzyskie Voivodship. The material used was data from the Local Data Bank of the Central Statistical Office and the Regional Accounting Chamber of Kielce for 2009-2017.

In the process of creating a synthetic measure, the following stages can be distinguished (Euczak, Wysocki, 2005):

I. Selection of simple features and their verification in terms of content and statistics (Wysocki, 2010). From the selected set of variables (Table 1), those with low spatial variability (coefficient of variation less than 0.10 ) and high correlation of variables (according to the inverse correlation matrix) were removed (Malina, 2004).

II. Determining the direction of feature preference in relation to the phenomenon under consideration (term destimulant and stimulant). Selected destimulants were replaced with a stimulant according to the formula;

$$
x_{i j}=\frac{1}{x_{i j}}
$$

III. Unitarization of features. The selected variables were subjected to the procedure of zero unitarisation using the following formulas:

$$
\text { for stimulants } z_{i j}=\frac{\mathrm{x}_{i j}-\min _{i} \mathrm{x}_{i j}}{\max _{i} \mathrm{x}_{i j}-\min _{i} x_{i j}} \text { when } x_{i} S
$$

where: $\mathrm{S}$ - stimulant, $\mathrm{D}$ - destimulant; $\mathrm{i}=1,2 \ldots \mathrm{n}$; $j=1,2 \ldots n$, xij - means the value of the $j$-th feature for the examined unit, max - the maximum value of the $j$-th feature, $\min$ - the minimum value of the $j$-th feature (Wysocki, Lira, 2005).

IV. Determination of synthetic measure according to the method based on distance in real space with the Euclidean metric according to the formula:

$$
O E_{i t}=\sqrt{\frac{1}{p} \sum_{j=1}^{p}\left(1-z_{i j t}\right)^{2}}
$$

where $i=1,2 \ldots N ; j=1,2 \ldots, p(N$ is the number of objects (poviats), ap - the number of features); zij - means the value of the $j$-th feature for the given unit, max - the maximum value of the $j$-th feature, min - the minimum value of the $j$-th feature (Wysocki, 1996). When the indicator value is equal to 0 , the given commune is characterized by the maximum value of each of the examined variables. The higher the value of this indicator, the worse the situation of the commune (Tokarski, 2005).

V. Linear ordering of objects and isolation of typological groups for the entire area of variability of the synthetic feature. The first, second and third quartiles were used as threshold values. The size of the synthetic measure in the first group means a better unit, in the last one the weakest. Correlation coefficients and scatter plots with a adjustment line for a synthetic measure were also presented (Zeliaś, Malina, 1997).

\section{The financial situation in theoretical terms}

Economic security is the ability of the economic system of the country (region) to make use of internal development factors that will guarantee its undamaged development (Frejtag-Mika, Kołodziejak, Putkiewicz, 1996) and formed the basis for the existential existence and survival of both individuals and wider social structures, local communities and nations (Red. M. Gębska, Kubiak, 2016).

Table 1

List of variables describing entrepreneurship potential in communes

\begin{tabular}{|l|c|}
\hline \multicolumn{1}{|c|}{ Variables } & S/D \\
\hline Total income - total expenditure / number of inhabitants (Surplus / budget deficit per capita (assessment of budget solvency) & S \\
\hline Interest / own income (debt service ratio) & D \\
\hline Total revenue / total expenditure (budget efficiency) & S \\
\hline Operating surplus / total revenues (in terms of budget solvency) & S \\
\hline Own income / total income (financial independence) & S \\
\hline Investment expenditure / total expenditure (in terms of investment attractiveness) & S \\
\hline Income from taxes and local fees / total income (S) level of fiscal wealth & S \\
\hline Total subsidies / total revenues (ratio of financial state interference) & D \\
\hline Total subsidies / income (financial interference ratio) & D \\
\hline Transport and communication expenditures / population (S) & S \\
\hline Expenditures on education and upbringing / population (S) & S \\
\hline Expenditures on housing / population (S) & S \\
\hline Expenditure on municipal management and environmental protection / number of inhabitants (S) & S \\
\hline Health care expenditure / population & S \\
\hline Expenditure on social policy / population (S) & S \\
\hline own debt / own income & D \\
\hline
\end{tabular}

as - stimulant; $\mathrm{d}$ - destimulant

Source: study based on data available at the Central Statistical Office of Poland (CSO) 
Based on the above statement, it can be said that economic security means a state, in which an individual, legal entity or territory has a feeling similar to certainty that they have and will have sufficient resources to cover their current needs and that there are no risky situations, that they could deprive these entities of their resources.

In this dimension, economic security means:

- stability of functioning;

- ability and potential to achieve goals;

- risk mitigation options;

- development opportunities, wealth creation;

- from the point of view of the funds needed - the possibility of obtaining them, likelihood of risk (almost impossible).

The role of public authorities in the responsibility for building and maintaining the economic security of each society is to conduct the appropriate socio-economic policy, making efforts at a basic level to ensure access to goods and services of the basic consumer basket (Duczkowska-Piasecka, 2017).

The essence of the concept of regional development is the issue related to the very concept of development, which is defined as "any long-term process of directional changes in which the following stages of transformation can be correctly distinguished, demonstrating a notable diversity of this object in a given respect" (Nowa encyklopedia powszechna PWN, 1996). The essence of development is a permanent quality improvement as a part of the process, which is a progressive action that allows to increase potential. Regional development is mainly related to issues connected to increasing the region's potential, but it should be noted that the region as a concept is defined both culturally, as well as administratively and politically, as well as economically (Pietrzyk, 2000). Regional division is associated with a number of regulations, but it should be noted that regional division applies to both physical and geographical as well as economic and spatial issues (Korenik, 2007).

The concept of regional development is a concept that is related to the perception of the region and its development within the following definitions (Głuszczuk, 2011):

- Systematic improvement of the competitiveness of business entities and the standard of living of the inhabitants, and an increase in the economic potential of the regions, which contributes to the socio-economic development of the country;

- Permanent increase in the standard of living of the inhabitants and economic potential in the scale of a given territorial unit;

- Sustainable growth of three elements: the economic potential of regions and their competitive strength, as well as the level and quality of life of residents, and also contributes to the development of the national community;

- Sustainable increase in the standard of living of the inhabitants and economic potential in the scale of a given territorial unit, as well as a permanent increase in the economic potential of the regions, their competitive strength, as well as the level and quality of life of the inhabitants;

- Development is also a process of positive changes in quantitative and qualitative growth associated with the functioning of the region and the supra-local socioterritorial system, which identifies with the specific features of space, economic structure, as well as social ties that result from the shared regional identity.

Therefore, regional development is largely associated with improving the quality of life of residents and raising the economic level of the region. It is worth pointing out that the technical and technological issue includes a number of changes that are to cause a gradual increase in the quality of goods and services produced, as well as the range of products and production capacity in the region (Nowacki, 2016).

When identifying the determinants of regional development, it should be pointed out that they are shaped in terms of various sources, as well as a cause and effect relationship, which is associated with further transformations. It is worth pointing out that the multi-faceted nature of regional development allows to distinguish determinants at the economic, social, technical and technological as well as ecological levels (Churski, 2015). The division of aspects is presented in Table 1, where individual aspects are distinguished and defined in terms of aspects concerning the division into individual categories.

Determinants of regional development are associated with the application of criteria for the spatial allocation of developmental driving forces, as well as the degree of their controllability and the type of relationship between the issue of development and the phenomenon of development, as well as the reasons for this development.

When discussing the activities of local entities in the process of shaping the development of the region providing security, first of all, the importance of Territorial Self-Government Units (JSTs), the operation of which is key in terms of economic security of the region, local development and shaping this development, should be pointed out. Therefore, it seems necessary to present the importance of local government.

The importance of local government is mainly associated with the functioning of the local community, as well as the functioning of the local community as a host in a given area. The self-government is actually a picture of decentralization of public authority, which is related to the performance of independent tasks carried out by a given local government unit, which have specific material resources to carry out specific public tasks (Imiołczyk, 2011). According to the European Charter of Local Government adopted in Strasbourg on October 15, 1985, ratified by Poland in 
Table 2

Determinants of regional development in the light of its aspects

\begin{tabular}{|c|c|}
\hline $\begin{array}{c}\text { Aspects of regional } \\
\text { development }\end{array}$ & Selected determinants of regional development \\
\hline Economical & $\begin{array}{l}\text { - increasing the regional capital; } \\
\text { - changing in the regional labor market quantitatively and qualitatively; } \\
\text { - setting favorable trends in the income or profits of regional entities (households, business entities, institutions and } \\
\text { local government bodies); } \\
\text { - growing intra-regional demand and pro-development changes in its structure; } \\
\text { - stimulating and supporting innovation; } \\
\text { - increasing the investment outlays within the region (investments of regional units and entities from outside the } \\
\text { region); } \\
\text { - improving the efficiency of the regional market of goods and services; } \\
\text { - setting constant, effective space marketing; } \\
\text { - modernizing management; } \\
\text { - achieving favorable economic situation in the country; } \\
\text { - achieving favorable economic situation on foreign markets; } \\
\text { - absorbing aid, including the EU. }\end{array}$ \\
\hline Social & $\begin{array}{l}\text { - shaping and strengthening regional awareness; } \\
\text { - improving the functioning of the local government community; } \\
\text { - stimulating and nurturing active social attitudes, including in the field of civic participation in regional and local } \\
\text { decision-making processes; } \\
\text { - creating and developing entrepreneurial attitudes; } \\
\text { - achieving positive shifts in the population age structure; } \\
\text { - improving the level of education permanently; } \\
\text { - enriching the professional qualifications systematically; } \\
\text { - improving intellectual infrastructure; } \\
\text { - progressing processes of urbanization, agglomeration and metropolization; } \\
\text { - improving social infrastructure and related services; } \\
\text { - improving the quality of life of residents (level, conditions and lifestyle). }\end{array}$ \\
\hline $\begin{array}{l}\text { Technical data and } \\
\text { technological }\end{array}$ & $\begin{array}{l}\text { - modernizing and expanding the material structure of the generating apparatus; } \\
\text { - improving the quality of production and services; } \\
\text { - intensifying research and development activities; } \\
\text { - achieving diversification of the region's economic profile, including increasing its share in the economy of the } \\
\text { so-called high technology sectors; } \\
\text { - supporting and strengthening the processes of implementing product innovations; } \\
\text { - improving technical infrastructure. }\end{array}$ \\
\hline Ecological & $\begin{array}{l}\text { - rationalizing the management of natural resources; } \\
\text { - promoting and developing ecological awareness of the region's inhabitants; } \\
\text { - implementing of pro-ecological technological solutions. }\end{array}$ \\
\hline
\end{tabular}

Source: D. Gtuszczuk, 2011, Istota rozwoju regionalnego i jego determinanty, [w]: Ekonomia, nr 5/2011, Wroctaw, s. 75.

1993, "local government means the right and ability of local communities, within the limits set by law, to direct and manage an essential part of public affairs on their own responsibility and in their interest residents" (Europejska Karta Samorządu Terytorialnego). It has its own independent bodies (included in public administration), operating independently within the limits set by law and subject to supervision and control on the principles set out in law. The essence of its activity is the management of public affairs by the social community being the subject of these tasks.

When analyzing the action related to the functioning of local government units, the municipality must be recognized as a key unit, which results from the fact that it is in the case of local government units that key actions regarding social functioning and functions related to the work of the local community are implemented. It is worth noting that, according to the provisions and letter of the Act, it is the rights that are not assigned to other JSTs that are just assigned to the function of JST.

Pursuant to the Act, the exclusive competences of the JST board include primarily (Niewiadomski, Siemiński, Sosnowski, Tetera, 2001):

- adopting economic plans and statuses of local government units, as well as budget units reporting to the commune;

- determining the composition, as well as electing and dismissing the management boards of local government units as well as municipal companies;

- setting the amount and type of local taxes and fees with the restriction resulting from central regulations; - undertaking cooperation with other municipalities; - adopting resolutions regarding JST finances, including incurring liabilities, issuing bonds, selling real estate, etc. 
- adopting the JST budget and ensuring its correct implementation;

- determining the directions of the commune head and accepting reports on his or her activities, as well as determining the amount of his or her remuneration;

- adopting plans related to the strategy and directions of JST development;

- determining the rules and amount of granting scholarships for pupils and students in JST;

- granting honorary citizenship of JST.

In terms of the functioning of the poviat authority, the issue of JST competences is important because the competences related to the operation of poviats and the operation of communes are to a large extent complementary and permeate, moreover, poviat authorities may outsource some of their own tasks resulting from the obligations related to the operation of poviat authorities, delegate on municipal authorities. At the same time, one cannot ignore the fact that in the case of cities with poviat rights, there is a situation related to the combination of competences related to the obligations arising from the rights of poviats and obligations arising from the rights of local government units.

Undoubtedly, therefore, regional development is conditioned by the cooperation of a factor related to the cooperation of a political center operating in a given region, enterprises, as well as conditions that cause a given region to develop. Conditions such as natural resources or business conditions are extremely important because the access to raw materials as well as to employees is currently a key factor for the development of a given industry sector in a given region.

Therefore, referring to the definition of local security and economic security being built, one cannot speak only about the fact that it aims to care for the community as a whole, but it should be added that it tends to ensure stability and security for every citizen (Wolski, 2018).

\section{Diversification of the financial situation of communes in the Świętokrzyskie Voivodship}

The economic security of the state should be treated as the security of the entire economic system and interpreted as "(...) undisturbed functioning of economies, that is, maintaining basic development indicators (...) at an unchanged or higher level" (Księżopolski, 2004). Economic security can be understood as "(...) the sum of conditions ensuring stability and prosperity of management processes, both on a microeconomic and macroeconomic scale" (Pięta, 2009). Economic security is directly connected with the issue of socio-economic development of the state. Economic security is constantly changing, which results from the specifics of the market economy, for which, among others, cyclical fluctuations (Dworakowska Małgorzata Magdalena).
The financial dimension of economic security is one of the four dimensions of economic security, such as: the raw material and energy dimension, food dimension and access to clean water (Por. K. M. Księżopolski, 2011). Financial security and trends of changes can be determined by the ratio of assets (or liabilities) to the balance sheet total. In financial terms, it is a guarantee of the existence and development of an institution (organization) that arises as a result of daily management efforts to ensure good financial condition. Therefore, it refers to all financial decisions we make in relation to property management. Financial security is a state (nonrisk) that gives a sense of confidence in the functioning of the entity and a chance for its development, or an intermediate state in building financial independence (Dziekański, 2014).

The study showed a diversified level of financial security for communes in the Świętokrzyskie voivodship. In 2018, the OE measure of financial security ranged from 0.66 (Sitkówka-Nowiny (2); the best unit) to 0.85 (Radków (2), Tarłów (2); the weakest units), and from 0.69 (Sitkówka-Nowiny (2)) to 0.87 (Gowarczów (2), Mirzec (2), Nowy Korczyn (2), Tarłów (2), Wąchock (3), Wiślica (2)) in 2009. The range of values adopted by the OE measure in 2009 is slightly higher (range 0.19) than in 2018 (range 0.18).

High in 2018 according to the measure of synthetic financial security: Sitkówka-Nowiny (2), Połaniec (3), Kielce (1), Busko-Zdrój (3), Morawica (2), Ożarów (3), Sandomierz (1), Masłów (2), Starachowice (1), SolecZdrój (2) 0,78, Końskie (3), Ostrowiec Świętokrzyski (1) (see Figure 1).

Map of spatial differentiation (Figure 2) indicates a distribution model for the synthetic measure of financial security of communes in the Świętokrzyskie Voivodship. The value of the synthetic measure in 2018 was $0.66-0.85$, range 0.19 , and $0.69-0.87$, range 0.19 in 2009 . The most numerous range in 2018 was $0.78-0.80$ ( 31 units), while $0.82-0.84$ and $0.84-0.86$ in 2009 (27 units each), which means that this range is dominant.

Measures of spatial diversity in the case of a synthetic measure of development in 2018 compared to 2009 show the stability of the studied phenomenon. This is indicated by the values of standard deviation (0.03-0.03), classic coefficient of variation (0.04-0.04), range (0.18-0.19; Table 2).

The Pearson correlation coefficient between the value of the synthetic measure of financial security in 2018 compared to 2009 according to the OE measure was 0.751 (Figure 3). Outbound units Sitkówka-Nowiny (2), Połaniec (3) and Kielce (1) - units with industrial function, Raków (2), Radków (2), Baćkowice (2), Mirzec (2) - units with traditional agricultural function.

There are significant correlations between the level of financial security measure, own revenues, local tax revenues, share in PIT and CIT revenues, the measure 


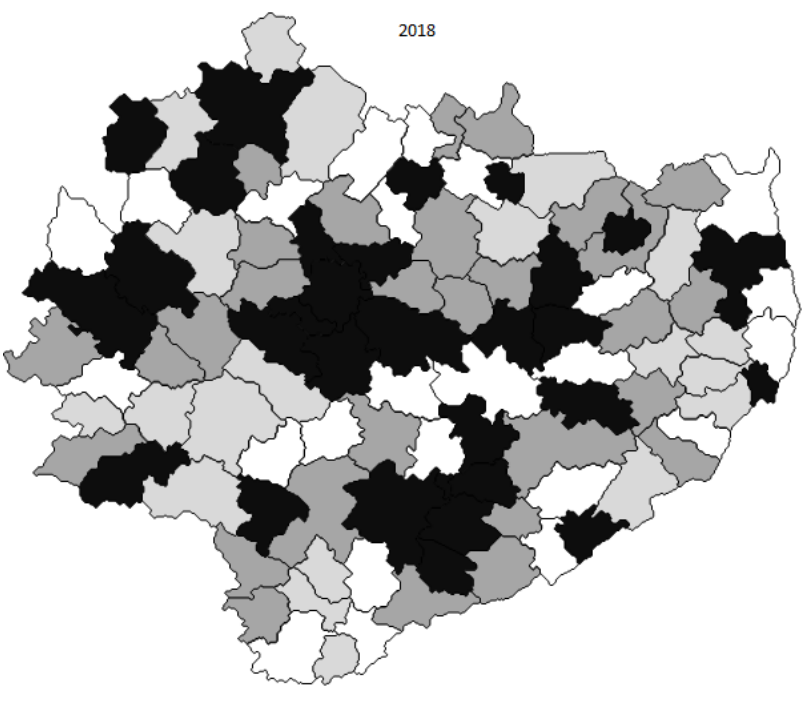

Gr I

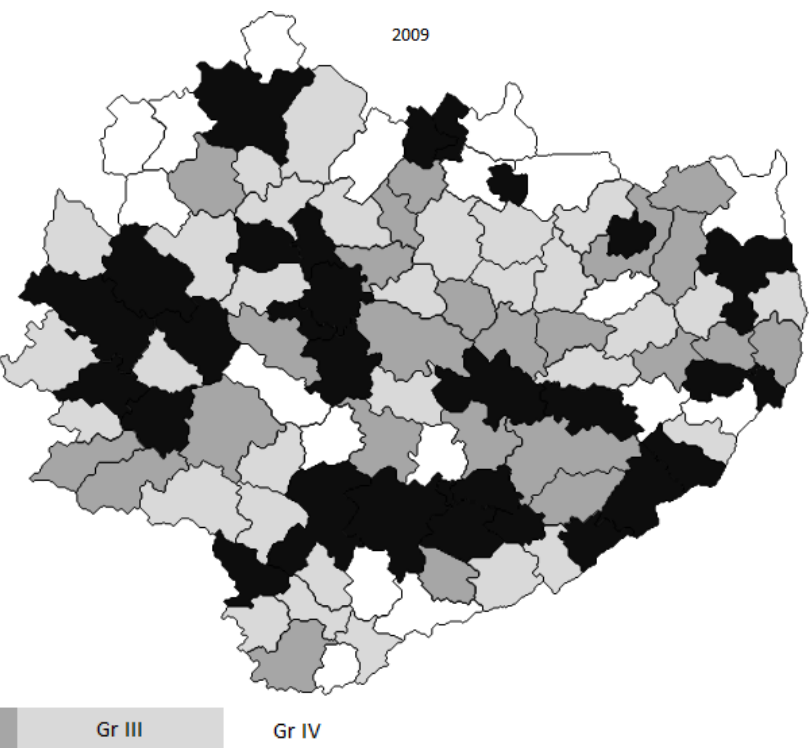

Figure 1. Spatial differentiation of the synthetic measure TOPSIS entrepreneurship of communes of the Świętokrzyskie Voivodship in 2009 and 2017

Source: the author's own development based on BDL GUS
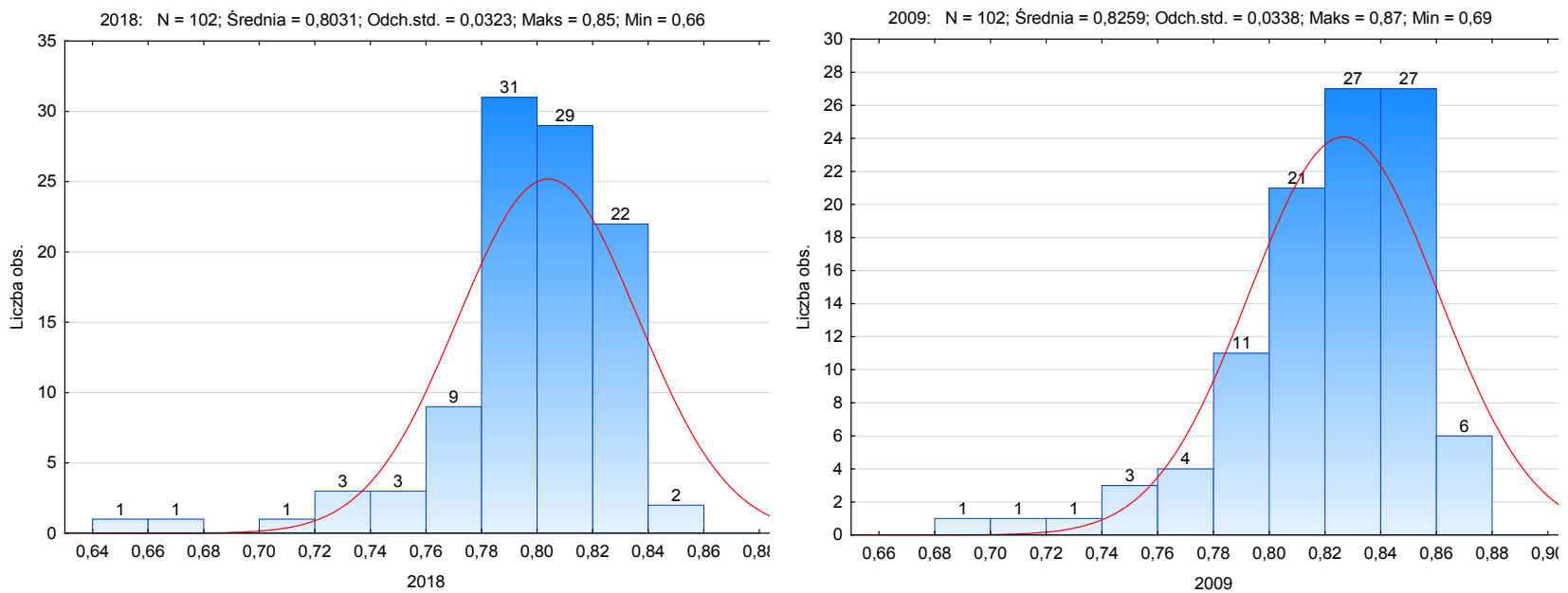

Figure 2. Map of spatial differentiation of a measure of synthetic financial security for communes in the Świętokrzyskie voivodship in 2009 and 2018

Source: the author's own development based on BDL GUS

Table 2

Differentiation of synthetic measure for communes in the Świętokrzyskie voivodship in 2009 and 2018

\begin{tabular}{|c|c|c|}
\hline & 2009 & 2018 \\
\hline average & 0.83 & 0.80 \\
\hline median & 0.83 & 0.81 \\
\hline standard deviation & 0.03 & 0.03 \\
\hline $\begin{array}{c}\text { classic coefficient } \\
\text { of variation }\end{array}$ & 0.04 & 0.04 \\
\hline min. & 0.69 & 0.66 \\
\hline max & 0.87 & 0.85 \\
\hline range & 0.18 & 0.19 \\
\hline
\end{tabular}

Source: the authors' own development based on BDL GUS of financing services, state interference, financing services, the number of unemployed and employed. The number of business entities indicates the level of entrepreneurship in the region. This is one of the indicators showing the economic situation of the region and having an impact on financial security next to financial variables (Table 3).

Regression analysis of the OE measure of financial security of communes in the Świętokrzyskie voivodship explains $\mathrm{R}=0.516$ variable variations. The model indicates the important role of the employed and the unemployed, business entities and natural persons conducting economic activity in the process of shaping the financial security of communes. Further increasing 


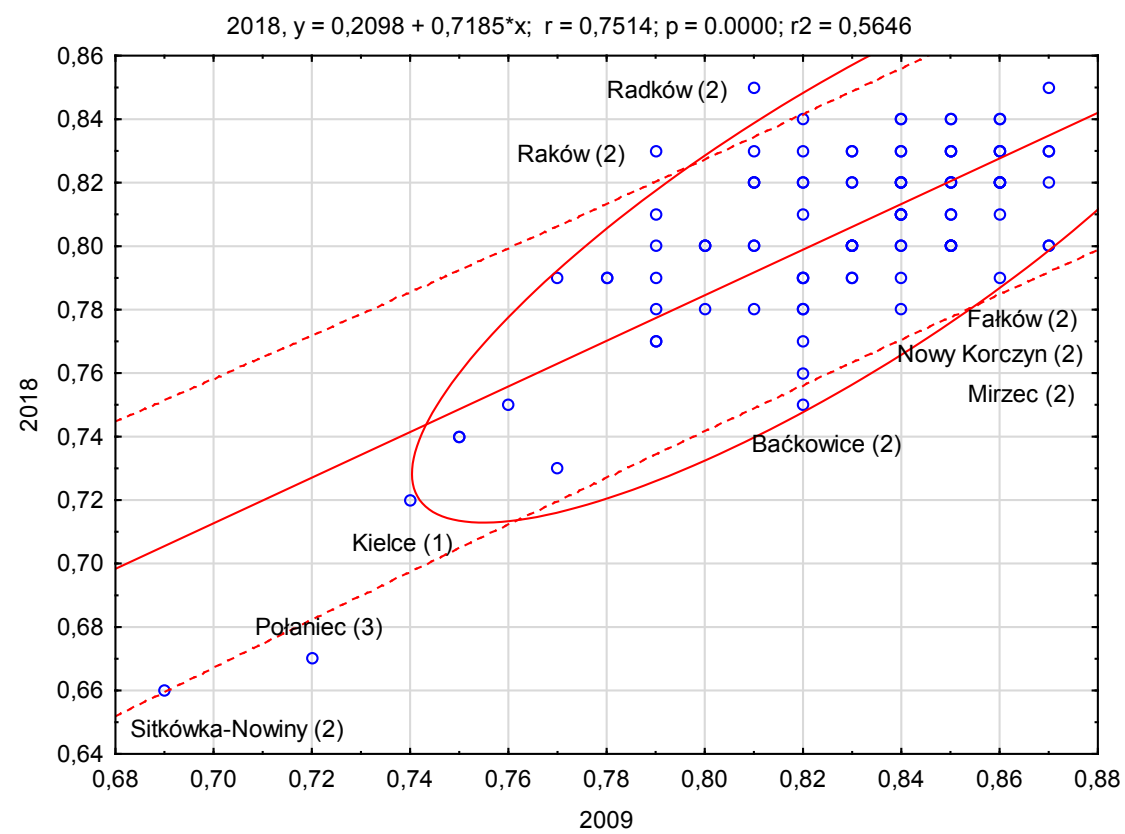

Figure 3. Year-to-year relation of the synthetic $\mathrm{OE}$ measure of financial security of communes of the Świętokrzyskie voivodship in 2009 and 2018.

Source: the author's own development based on BDL GUS

the multidimensionality of the model would cause a slight increase in $\mathrm{R}^{2}=0.496^{1}$ (Table 4).

\section{Table 3}

Correlation between measures of financial security and socio-economic variables of rural communes in the Świętokrzyskie Voivodship

\begin{tabular}{|l|l|}
\hline & $\begin{array}{c}\text { OE Financial } \\
\text { Security }\end{array}$ \\
\hline Own income & -0.8136 \\
\hline Income from local taxes & -0.781 \\
\hline Revenue share, PIT & -0.6171 \\
\hline Share in CIT income & -0.7164 \\
\hline Capital expenditure & -0.4585 \\
\hline Measure the budget solvency & 0.5759 \\
\hline Measure of state interference & 0.751 \\
\hline Measure the level of financed services & 0.6392 \\
\hline Number of persons employed & -0.6603 \\
\hline Number of unemployed & 0.1487 \\
\hline Economic operators & -0.4414 \\
\hline Self-employed persons & -0.3984 \\
\hline A measure of development & 0.6407 \\
\hline A measure of entrepreneurship & 0.4974 \\
\hline Infrastructure measure & 0.3962 \\
\hline A measure of demography & 0.4489 \\
\hline Measure of the environment & -0.106 \\
\hline
\end{tabular}

Linear correlation coefficients for observations from sample 1-102 Critical value (at a double-sided 5\% critical area) $=0.1946$ for $\mathrm{n}=102$ Source: the authors' own development based on BDL GUS

\section{Conclusion}

Security is generally defined as the absence of threats and risks. However, it is worth noting that "certainty of no threats", by the way "no threats" is an ideal type, which is a primitive definition of security, would exclude the possibility of the phenomenon of security at all. Therefore, such certainty would also preclude the existence of any need to conduct research in a pointless scope (Piwowarski, 2018).

Security, as a complex matter, is universal and ambiguous in nature, as it can relate to many aspects of the functioning of individuals, families, groups, communities as well as the entire society and the entire state. Therefore, in order to define its specificity, it is necessary to add an appropriate adjective to it (PolcynRadomska, 2014).

Economic security is expressed primarily in the economy's ability to survive and develop. The greater the economic potential of the national economy, is at a higher level of socio-economic development and shows faster growth dynamics, the more stable and durable its security is considered.

The study showed a diversified level of financial security for communes in the Świętokrzyskie voivodship. In 2018, the measure of the level of financial security ranged from 0.65 to 0.85 , while from 0.69 to 0.87 in 2009 .

There are significant correlations between the level of financial security measure, own revenues, local tax revenues, share in PIT and CIT revenues, the measure

\footnotetext{
${ }^{1}$ Skorygowany współczynnik determinacji nie osiągnął 60\%.Za optymalną wartość uważa się przekroczenie progu determinacji na poziomie $95 \%$
} 
Table 4

Regression analysis of synthetic safety of municipalities in the Świętokrzyskie voivodship

\begin{tabular}{|l|c|c|c|c|}
\hline & Factor & Standard error & t-Student's & $\mathrm{p}$-value \\
\hline Constant & 0.830358 & 0.00927890 & 89.49 & $<0.0001$ \\
\hline Number of persons employed & -0.000290823 & $4.19709 \mathrm{e}-05$ & -6.929 & $<0.0001$ \\
\hline Number of unemployed & 0.000192206 & $7.15878 \mathrm{e}-05$ & 2.685 & 0.0085 \\
\hline Economic operators & 0.00131541 & 0.000626777 & 2.099 & 0.0384 \\
\hline Self-employed persons & -0.00169275 & 0.000680266 & -2.488 & 0.0145 \\
\hline
\end{tabular}

\begin{tabular}{|l|c|l|c|}
\hline Arithmetic mean of the dependent variable & 0.803137 & Standard deviation of the dependent variable & 0.032304 \\
\hline Sum of residual squares & 0.050934 & Residual standard error & 0.022915 \\
\hline Determining coefficient R- square & 0.516733 & Corrected R-square & 0.496804 \\
\hline F (4.97) & 25.92927 & P-value for the F test & $1.26-14$ \\
\hline Logarithm of credibility & 242.9799 & Information criteria Akaike & -475.9597 \\
\hline Bayesian, Schwarz information criterion & -462.8349 & Hannan-Quinn criterion & -470.6450 \\
\hline
\end{tabular}

MNC estimation; observations 1-102 used; Dependent variable OE financial security

Source: the authors' own development based on BDL GUS

of financing services, state interference, financing services, the number of unemployed and employed. Outbound units Sitkówka-Nowiny (2), Połaniec (3) and Kielce (1) - units with industrial function, Raków (2), Radków (2), Baćkowice (2), Mirzec (2) - units with traditional agricultural function.

\section{References:}

Churski, P. (2015). Czynniki rozwoju regionalnego i polityka regionalna w Polsce w okresie integracji z Unią Europejską, Wydawnictwo UAM, Poznań.

Duczkowska-Piasecka, M. (2017). Rola innowacji w umacnianiu bezpieczeństwa ekonomicznego, Journal of Modern Science tom 2/33/2017.

Dworakowska, M. M. (2015). Bezpieczeństwo ekonomiczne jednostek samorządu terytorialnego w Polsce Journal of Modern Science, no. 1(24).

Dziekański, P. (2014). Bezpieczeństwo ekonomiczne wyzwaniem współczesnego regionu - próba oceny syntetycznej, „Kultura bezpieczeństwa. Nauka - Praktyka - Refleksje”, nr 16.

Dziekański, P. (2016). Spatial Differentiation of the Financial Condition of the Świętokrzyskie Voivodship Counties. Barometr Regionalny, Tom 14, nr 3.

Europejska Karta Samorządu Terytorialnego, Dz. U. z 1994 roku, Nr 124, poz. 607 z późn. zm.

Frejtag-Mika, E., Kołodziejak, Z., \& Putkiewicz, W. (1996). Bezpieczeństwo ekonomiczne we wspótczesnym świecie, Wydawnictwo Politechniki Radomskiej, Radom.

Gębska, M., \& Kubiak, M. (2016). Wspótczesne bezpieczeństwo ekonomiczne, Wymiar międzynarodowy, Akademia Sztuki Wojennej, Warszawa.

Głuszczuk, D. (2011). Istota rozwoju regionalnego i jego determinanty, [w]: Ekonomia, nr 5/2011, Wrocław.

Imiołczyk, B. (red.) (2011). ABC Samorządu terytorialnego (poradnik nie tylko dla radnych), Fundacja Rozwoju Demokracji Lokalnej, Warszawa.

Kukuła, K. (2000). Metoda unitaryzacji zerowanej, PWN, Warszawa.

Kitler, W. (2010). Bezpieczeństwo narodowe. Podstawowe kategorie, dylematy pojęciowe i próba systematyzacji, TWO, Zeszyt Problemowy 1(61).

Korenik, S. (2007). Pojęcie i znaczenie przestrzeni, [w:] Stosunki samorządowo-bankowe a rozwój społecznoekonomiczny w przestrzeni, CeDeWu.pl, Warszawa.

Księżopolski, K. M. (2004). Ekonomiczne zagrożenie bezpieczeństwa państw. Metody i środki przeciwdziałania. Warszawa: Kolor Plus.

Księżopolski, K. M. (2011). Bezpieczeństwo ekonomiczne, Warszawa.

Łuczak, A., \& Wysocki, F. (2005). Wykorzystanie metod taksonometrycznych i analitycznego procesu hierarchicznego do Malina A., (2004) Wielowymiarowa analiza przestrzennego zróżnicowania struktury gospodarki Polski według województw, Wyd. Akademii Ekonomicznej w Krakowie, Kraków.

Młodak, A. (2006). Analiza taksonomiczna $w$ statystyce regionalnej, Centrum Doradztwa i Informacji Difin, Warszawa.

Niewiadomski, Z., Siemiński, W., Sosnowski, P., \& Tetera, M. (2001). Samorząd terytorialny. Ustrój i gospodarka, Branta, Bydgoszcz. 
Nowa encyklopedia powszechna PWN (1996). PWN, Warszawa, t. 5.

Nowacki, R. (2016). Potencjał innowacyjny regionu jako czynnik rozwoju regionalnego, [w:] R. Brol (red.), Gospodarka lokalna i regionalna w teorii i praktyce, Wydawnictwo UE we Wrocławiu, Wrocław.

Nowak, E. (1990). Metody taksonomiczne w klasyfikacji obiektów społeczno-gospodarczych, PWE, Warszawa.

Pietrzyk, L. (2000). Polityka regionalna Unii Europejskiej i regiony w państwach członkowskich, PWN, Warszawa. Pięta, K. (2009). Zróżnicowanie bezpieczeństwa ekonomicznego państw w dobie globalizacji. W: J. Pięta i B. Purski (red.), Współczesne dylematy bezpieczeństwa - teoria i praktyka (ss. 163-172). Warszawa: Wydawnictwo Naukowe Wyższej Szkoły Bezpieczeństwa i Ochrony.

Piwowarski, J. (2018). Nauki o bezpieczeństwie, Między kulturą bezpieczeństwa a studiami bezpieczeństwa, Warszawa.

Polcyn-Radomska, A. (2014). Wartość, znaczenie i uwarunkowania bezpieczeństwa narodowego, Kwartalnik naukowy, nr 1(17).

Stańczyk, J. (1996). Wspótczesne pojmowanie bezpieczeństwa, Warszawa.

programowania rozwoju obszarów wiejskich. Wydawnictwo Akademii Rolniczej im. Augusta Cieszkowskiego w Poznaniu, Poznań.

Tokarski, T. (2005). Statystyczna analiza regionalnego zróżnicowania wydajności, zatrudnienia i bezrobocia $w$ Polsce, Wydawnictwo PTE, Warszawa.

Trojak,M., \& Tokarski, T. (red.) (2013). Statystyczna analiza przestrzennego zróżnicowania rozwoju ekonomicznego i społecznego Polski, Wyd. UJ, Kraków.

Wolski, A. (2018). Bezpieczeństwo personalne na gruncie społeczności lokalnej, Zeszyty Naukowe Wyższej Szkoły Zarządzania Wysocki F., (2010), Metody taksonomiczne w rozpoznawaniu typów ekonomicznych rolnictwa i obszarów wiejskich. Wyd. Uniwersytetu Przyrodniczego w Poznaniu, Poznań.

Wysocki, F., \& Lira, J. (2005). Statystyka opisowa, Wyd. AR, Poznań.

Wysocki, F. (1996). Metody statystycznej analizy wielowymiarowej w rozpoznawaniu typów struktury przestrzennej rolnictwa, Roczniki AR w Poznaniu, seria: Rozprawy Naukowe, z. 266, Poznań.

Zeliaś, A., \& Malina, A. (1997). O budowie taksonomicznej miary jakości życia. Syntetyczna miara rozwoju jest narzędziem statystycznej analizy porównawczej, Taksonomia z. 4 Ochroną Pracy w Katowicach, nr 1(14). 